\title{
Detection of Noroviruses in Foods: A Study on Virus Extraction Procedures in Foods Implicated in Outbreaks of Human Gastroenteritis
}

\author{
SASKIA A. RUTJES, ${ }^{1 *}$ FROUKJE LODDER-VERSCHOOR, ${ }^{1}$ WIM H. M. VAN DER POEL, ${ }^{1}$ \\ YVONNE T. H. P. VAN DUIJNHOVEN, ${ }^{2}$ AND ANA MARIA DE RODA HUSMAN ${ }^{1}$
}

\begin{abstract}
${ }^{1}$ Microbiological Laboratory for Health Protection, Centre for Infectious Disease Control, National Institute of Public Health and the Environment, P.O. Box 1/ Antonie van Leeuwenhoeklaan 9, 3720 BA Bilthoven, The Netherlands; and ${ }^{2}$ Centre for Infectious Disease Epidemiology, National Institute of Public Health and the Environment, Bilthoven, The Netherlands
\end{abstract}

MS 05-609: Received 30 November 2005/Accepted 25 March 2006

\begin{abstract}
Disease outbreaks in which foods are epidemiologically implicated as the common source are frequently reported. Noroviruses and enteric hepatitis A viruses are among the most prevalent causative agents of foodborne diseases. However, the detection of these viruses in foods other than shellfish is often time-consuming and unsuccessful. In this study, three virus concentration methods were compared: polyethylene glycol (PEG) plus $\mathrm{NaCl}$, ultracentrifugation, and ultrafiltration. Two RNA extraction methods, TRIzol and RNeasy Mini Kit (Qiagen), were compared for detection of viruses in whipped cream and lettuce (as representatives of the dairy and vegetable-fruit food groups, respectively). A seeding experiment with canine calicivirus was conducted to determine the efficiency of each virus extraction procedure. The PEG-NaCl-TRIzol method was most efficient for the detection of viruses in whipped cream and the ultracentrifugation-RNeasy-Mini Kit procedure was best for detection on lettuce. Based on the seeding experiments, food items implicated in norovirus-associated gastroenteritis outbreaks were subjected to the optimal procedure for a specific composition and matrix. No noroviruses were detected in the implicated food items, possibly because the concentration of virus on the food item was too low or because of the presence of inhibitory factors. For each food group, a specific procedure is optimal. Inhibitory factors should be controlled in these procedures because they influence virus detection in food.
\end{abstract}

Norovirus and hepatitis A are the most common causes of foodborne viral gastroenteritis and hepatitis worldwide $(24,25)$. To a lesser extent, rotaviruses, enteroviruses, astroviruses, and hepatitis E virus also are important (33, 4446, 52). Noroviruses, previously known as Norwalk-like viruses, are a genetically diverse group of RNA viruses belonging to the family Caliciviridae. Genetically, noroviruses can be divided into five genogroups (GGI, GGII, GGIII, GGIV, and GGV), which consist of different genotypes. A prototype virus represents each genotype: GGI includes Norwalk virus (GGI-1) and Southampton virus (GGI-2), GGII includes Hawaii virus (GGII-1) and others $(1,51)$, GGIII includes Jena virus, GGIV includes Alphatron, and GGV is found in mice. Norovirus infections can cause vomiting, diarrhea, and nausea within 24 to $48 \mathrm{~h}$ after exposure (34). Hepatitis A virus causes an acute infection of the liver, with fever, nausea, headache, and jaundice (7). Outbreaks of norovirus and hepatitis A virus infections occur throughout the world. In the United States, England, Wales, and The Netherlands, 60 to $70 \%$ of the reported gastroenteritis outbreaks are caused by noroviruses $(14,32$, $48,50)$. These outbreaks have occurred in various settings such as nursing homes (5), hospitals (50), cruise ships (21), schools and universities (23), and restaurants and events

* Author for correspondence. Tel: +31 30274 3272; Fax: +31 30274 4434; E-mail: saskia.rutjes@ @rivm.nl. with catered meals (36). Transmission has occurred by person-to-person contact (6) and through contaminated water $(10,19)$ and food $(20,36,37)$. Most of the food items implicated in these outbreaks are raw or uncooked, such as oysters, mussels, fruits, vegetables, sandwiches, dairy products, baked products, and salads, which are associated with high risks of infection $(3,9,18,20,27,39,40)$. These foods are most likely contaminated through sewage-contaminated surface water or by infected food handlers during harvesting, packaging, or food preparation $(9,35)$. Epidemiological investigations of outbreaks have been hindered by a lack of animal models or cell culture systems for the detection of noroviruses and hepatitis A virus in foods other than shellfish. However, hepatitis A virus and noroviruses can be detected with PCR-based methods $(3,50)$.

A few procedures have been developed for the detection of viruses in foods such as fruits and vegetables (11), fresh produce (8), ham, turkey, and roast beef (43), and lettuce and hamburger (42). The efficacy of these procedures for virus detection on lettuce was compared in a round-robin study in France (29). The aim of the current study was to develop procedures for the concentration and extraction of human pathogenic viruses from various types of food. The efficacy of the selected procedures for detecting viruses in naturally contaminated food items associated with gastroenteritis outbreaks was determined. 


\section{MATERIALS AND METHODS}

Viruses. Canine calicivirus $(\mathrm{CaCV})$ was used in the seeding experiments at a concentration of $2.5 \times 10^{6} \mathrm{TCID}_{50}(50 \%$ tissue culture infective dose) per ml. RNA was extracted from a nonseeded food item as a negative control. Human norovirus genogroup II RNA was used as a positive norovirus reverse transcription (RT) PCR control.

Food samples. Whipped cream and leaf lettuce were both obtained from local commercial sources. Naturally contaminated food items were acquired from outbreaks in which foodborne gastroenteritis was implicated (48).

Artificial contamination of whipped cream and leaf lettuce. To be able to directly compare different viral RNA extraction procedures for whipped cream and leaf lettuce, $5 \mathrm{~g}$ of each food product was seeded with $\mathrm{CaCV}$ at either $2.5 \times 10^{4}$ or 2.5 $\times 10^{5}$ TCID $_{50}$ during the first washing step of the virus concentration procedure. For the comparison of procedures, the artificially contaminated food items were tested in duplicate.

Virus concentration and RNA extraction procedures. For the extraction of viruses from foods, three types of virus concentration methods that have been previously used for the isolation of enteric viruses from lettuce (29) were compared; polyethylene glycol (PEG)-NaCl precipitation, ultracentrifugation, and ultrafiltration. For the extraction of viral RNA, two RNA extraction methods were selected: a TRIzol method and the RNeasy Mini Kit (Qiagen, Hilden, Germany). To determine the viral input, $\mathrm{CaCV}$ at $2.5 \times 10^{5} \mathrm{TCID}_{50}$ was extracted with each RNA extraction method.

PEG-NaCl precipitation. Five grams of food product was added to $4 \mathrm{ml}$ of phosphate-buffered saline (PBS; $\mathrm{pH}$ 7.2) in a $50-\mathrm{ml}$ tube, vortexed, and rotated for $5 \mathrm{~min}$. The supernatant was decanted into a clean 50-ml tube, and the washing step was repeated. Five milliliters of VertrelXF $(1,1,1,2,3,4,4,5,5,5$-decafluorpentane, Fluka, Steinheim, Switzerland) (35) was added to the supernatant, vortexed, and rotated for $5 \mathrm{~min}$. The sample was centrifuged for $10 \mathrm{~min}$ at $5,000 \times g$ at $4^{\circ} \mathrm{C}$. After centrifugation, the supernatant was added to a final concentration of $10 \%$ PEG- 0.3 $\mathrm{M} \mathrm{NaCl}$ in a clean 50-ml tube. This mixture was rotated during incubation for $2 \mathrm{~h}$ at $4^{\circ} \mathrm{C}$. After centrifugation for $30 \mathrm{~min}$ at 9,500 $\times g$ at $4^{\circ} \mathrm{C}$, the supernatant was decanted, and the pellet was resolved in either $100 \mu \mathrm{l}$ of PBS followed by RNA extraction using the RNeasy Mini Kit or in $1 \mathrm{ml}$ of TRIzol.

Ultracentrifugation. Five grams of food product was added to $4 \mathrm{ml}$ of PBS ( $\mathrm{pH} 7.2$ ) in a 50-ml tube, vortexed, and rotated for $5 \mathrm{~min}$. The supernatant was decanted into a clean 50-ml tube, and the PBS wash step was repeated. Five milliliters of VertrelXF was added to the supernatant, vortexed, and incubated with rotation for $30 \mathrm{~min}$ at room temperature. Then the sample was centrifuged for $20 \mathrm{~min}$ at $13,000 \times g$ at $4^{\circ} \mathrm{C}$. The supernatant was decanted into an ultracentrifuge tube (Beckman Coulter, Fullerton, Calif.) and centrifuged for $2 \mathrm{~h}$ at $120,000 \times g$. The supernatant was decanted, and the pellet was resuspended in either $100 \mu \mathrm{l}$ of PBS followed by RNA extraction using the RNeasy Mini Kit or in $1 \mathrm{ml}$ of TRIzol.

Ultrafiltration. Concentration of viruses can also be achieved by ultrafiltration using Centricon Plus-20 filters $(100,000$ nominal molecular weight limit; Biomax-100, Amicon, Millipore, Etten-Leur, The Netherlands). Five grams of food product was added to $10 \mathrm{ml}$ of glycine buffer (glycine- $\mathrm{NaCl}, \mathrm{pH} 9.5$ ) in a 50$\mathrm{ml}$ tube and shaken for $15 \mathrm{~min}$ at room temperature. The $\mathrm{pH}$ was adjusted to 9.5. The supernatant was decanted and centrifuged for $10 \mathrm{~min}$ at $10,000 \times \mathrm{g}$. This supernatant was transferred to the microconcentrator (Centricon Plus-20, Amicon) and reduced to a volume of 100 to $200 \mu \mathrm{l}$ by centrifugation at a maximum speed of $4,000 \times g$ at $4^{\circ} \mathrm{C}$ for 10 to $40 \mathrm{~min}$, depending on the viscosity of the sample. The virus concentrate was stored at $4^{\circ} \mathrm{C}$ until extraction of viral RNA with TRIzol or with the RNeasy Mini Kit.

TRIzol RNA extraction. For the extraction of viral RNA, the virus pellet was dissolved in TRIzol with a maximum of $10 \%$ sample volume per $1 \mathrm{ml}$ of TRIzol (Invitrogen, Live Technologies, Auckland, New Zealand) and incubated for $5 \mathrm{~min}$ at room temperature. After incubation, $200 \mu \mathrm{l}$ of chloroform per $1 \mathrm{ml}$ of TRIzol was added, and the solution was vortexed and centrifuged for $20 \mathrm{~min}$ at $16,100 \times g$ at $4^{\circ} \mathrm{C}$. The upper aqueous phase was transferred to a clean Eppendorf tube, and $10 \mu \mathrm{l}$ of silica (2) was added. After vortexing, the mixture was incubated for $30 \mathrm{~min}$ at room temperature under rotation. After centrifugation for $30 \mathrm{~s}$ at $16,100 \times g$, the supernatant was decanted. The silica pellet was washed three times with $400 \mu \mathrm{l}$ of $70 \%$ ethanol and once with $400 \mu \mathrm{l}$ of acetone. After removal of the supernatant, the pellet was dried for $5 \mathrm{~min}$ at $56^{\circ} \mathrm{C}$. RNase-free water $(35 \mu \mathrm{l})$ was added, and the silica beads were vortexed and incubated for $30 \mathrm{~min}$ at a temperature of $56^{\circ} \mathrm{C}$. The sample was centrifuged for $1 \mathrm{~min}$ at $16,100 \times g$, and the supernatant was transferred to a clean Eppendorf tube. Viral RNA was stored at $-70^{\circ} \mathrm{C}$ until further testing.

RNeasy Mini Kit RNA extraction. Viral RNA extraction using the RNeasy Mini Kit was mainly performed as described by the manufacturer (plant and fungi protocol). Viral RNA was resuspended in $35 \mu$ l of RNase-free water and stored at $-70^{\circ} \mathrm{C}$ until further testing.

Norovirus and CaCV RT-PCR. For the detection of noroviruses, a single round RT-PCR was employed using the specific forward primer JV12Y and the reverse primer JV13I as previously described (49). For the detection of norovirus type Birmingham, the specific forward primer JV12BH (5'-GTTTCATTAT GATGCTGACTA- $3^{\prime}$ ) and reverse primer NVP110 (5'-AC(A/ T/G)AT(C/T)TCATCATCACCATA-3') were selected. For the detection of $\mathrm{CaCV}$, the specific reverse primer YGDD (5'-AATCTCATCATCACCATAAGT-3') and forward primer BR1 (5'CTGGGGWTGYGAYGTTGG-3') were used (12). The RT-PCR was performed in 0.6-ml tubes in a thermocycler 480 (Perkin Elmer, Norwalk, Conn.). Complementary DNA synthesis was started by incubating a mixture of $1 \mu \mathrm{l}$ of primer stock $(50 \mathrm{pmol} / \mu \mathrm{l})$, $3 \mu \mathrm{l}$ of water, and $5 \mu \mathrm{l}$ of RNA for $2 \mathrm{~min}$ at $95^{\circ} \mathrm{C}$ and then cooling this mixture at $4^{\circ} \mathrm{C}$ for $2 \mathrm{~min}$. A total volume of $6 \mu \mathrm{l}$ of the RT mix was prepared (containing $10 \mathrm{mM}$ Tris- $\mathrm{HCl}, 50 \mathrm{mM} \mathrm{KCl}, 3$ $\mathrm{mM} \mathrm{MgCl}_{2}, 1 \mathrm{mM} \mathrm{dNTPs}$, and $5 \mathrm{U} / \mu \mathrm{l}$ avian myeloblastosis virus reverse transcriptase) and added to $9 \mu \mathrm{l}$ of the RNA mix. Subsequently, cDNA was heated for $5 \mathrm{~min}$ at $95^{\circ} \mathrm{C}$ and then cooled at $4^{\circ} \mathrm{C}$ for $5 \mathrm{~min}$. A 5 - $\mu \mathrm{l}$ volume of $\mathrm{cDNA}$ was added to $45 \mu \mathrm{l}$ of PCR mix containing $10 \mathrm{mM}$ Tris- $\mathrm{HCl}(\mathrm{pH} \mathrm{9.2),} 75 \mathrm{mM} \mathrm{KCl}$, $1.5 \mathrm{mM} \mathrm{MgCl} 2,0.2 \mathrm{mM}$ dNTPs, $2.5 \mathrm{U} / \mu \mathrm{l} \mathrm{Taq}$ polymerase, and $15 \mathrm{pmol}$ of each primer. After RT-PCR, the products were visualized by electrophoresis in a $2 \%$ agarose gel. RT-PCR amplification was confirmed by Southern blot hybridization using a mix of four probes specific for human genogroups 1 and 2 (UK3, 5'GTCCCCTGACATCATACAGGCT-3'; JV5, 5'-TCACCAGA GGTTGTCCAAGC-3'; GG1, 5'-ATGGAYGTTGGYGAYTATG T-3'; and GG2, 5'-GAAYTCCATCRCCCAYTG-3') (47) for the detection of norovirus and a $\mathrm{CaCV}$-specific probe (5'-CAGGTA GGGATCAATATGGA-3') for the detection of CaCV. 
TABLE 1. Virus concentration methods followed by RNA extraction using either TRIzol or RNeasy Mini Kit

\begin{tabular}{llll}
\hline \multicolumn{1}{c}{ Method } & \multicolumn{1}{c}{ Elution step } & Concentration step & \multicolumn{1}{c}{ RNA extraction step } \\
\hline PEG-NaCl precipitation & PBS Vertrel XF & PEG-NaCl & TRIzol or RNeasy Mini Kit (Qiagen) \\
Ultracentrifugation & PBS + Vertrel XF & Ultracentrifugation & TRIzol or RNeasy Mini Kit \\
Ultrafiltration & Glycine buffer, adjust pH to $\geq 9.5$ & Ultrafiltration & TRIzol or RNeasy Mini Kit \\
\hline
\end{tabular}

Hybridization. For Southern blotting, the CaCV and norovirus RT-PCR products in the agarose gel were transferred to a positively charged nylon membrane (Boehringer, Almere, The Netherlands) by vacuum blotting (Millipore) in a blot buffer containing $0.5 \mathrm{M} \mathrm{NaOH}$ and $0.6 \mathrm{M} \mathrm{NaCl}$. Southern blot hybridization of norovirus and $\mathrm{CaCV}$ were performed at $42^{\circ} \mathrm{C}$. After hybridization, the bound probe was visualized by enhanced chemiluminescence detection (Roche Diagnostics, Almere, The Netherlands).

Sequencing. Positive RT-PCR fragments were processed by purifying the PCR products with a PCR purification kit (Qiagen) and sequenced with the BigDye Terminator Cycle Sequencing Ready Reaction. Nucleotide sequences were edited with Seqman II and aligned by Bionumerics (version 2.0, Applied Maths, Kortrijk, Belgium) using the unweighted pair group method with arithmetic mean (UPGMA) after multiple sequence alignment of a 145-nucleotide segment of the polymerase gene.

\section{RESULTS}

Seeding experiments. The most sensitive and standardized procedure for the detection of pathogenic viruses in food items was established by performing seeding experiments. Lettuce and whipped cream were seeded with $\mathrm{CaCV}$ at $2.5 \times 10^{5} \mathrm{TCID}_{50} / \mathrm{ml}$ during the first washing step. Virus concentration methods were PEG-NaCl precipitation, ultracentrifugation, or ultrafiltration. A summary of the three virus concentration methods is given in Table 1 . RNA was extracted with TRIzol or with the RNeasy Mini Kit. The loss of virus particles during virus concentration and viral RNA extraction procedures was estimated in 10fold serial endpoint dilutions by CaCV RT-PCR and hybridization. Virus recovery results for lettuce and whipped cream are given in Table 2. For seeded lettuce, a loss of 10 to 1,000 PCR-detectable CaCV units was observed depending on the method, and the ultracentrifugation-RNeasy Mini Kit procedure was the most efficient method. For seeded whipped cream, the same range of virus loss was found. However, the most efficient procedure for this dairy product was achieved by the combination $\mathrm{PEG}-\mathrm{NaCl}$ precipitation and TRIzol.
Food items implicated in outbreaks. In 2002, food was collected during seven norovirus-associated gastroenteritis outbreaks in a 1-year intensive study of outbreaks of gastroenteritis in The Netherlands (Table 3) (48). Of these seven norovirus outbreaks, two were associated with GGII.4 Grimsby viruses and two were associated with GGI.3 Birmingham viruses. In the remaining three outbreaks, noroviruses were not specified (Table 3). A total of 42 food items that might have been involved in the outbreaks were collected. Evidence for involvement of the implicated food item was mainly based on descriptive information and not on analytical case-control or cohort studies.

The food items were categorized: 9 were dairy, 20 were meat, 8 were fruits or vegetables, and 5 were grains (Table 4). Primers JV12Y and JV13I were used for detection of noroviruses in food items associated with outbreaks 1 and 4 through 7, in which GGII.4 Grimsby or unspecified noroviruses were detected in the fecal samples of affected individuals. In outbreaks 2 and 3, norovirus strain GGI.3 Birmingham was implicated as the causative viral agent, which is less well-amplified with these primers and therefore the alternative primer set JV12BH and NVP110 was used. The number of food items implicated in one outbreak ranged from 2 to 17 (Table 4). Those fruit-vegetable or dairy food items that were collected separately were tested using the ultracentrifugation-RNeasy Mini Kit or PEG$\mathrm{NaCl}$ precipitation-TRIzol procedure, respectively, with minor changes (Table 5). For the five mixed-food items containing a dairy component (applesauce, tomato, ginger, pickled ice, and pickled salad), the PEG-NaCl precipitation-TRIzol procedure was applied. For all tested food items, 93\% were tested with the PEG-NaCl precipitationTRIzol procedure and 7\% were tested with the ultracentrifugation-RNeasy Mini Kit procedure. Noroviruses were not detected in any of the 42 samples. One food sample produced a PCR fragment of the expected size for norovirus after gel electrophoreses, but this positive signal could not be confirmed by specific hybridization. Sequencing of this

TABLE 2. RT-PCR results of different CaCV extraction procedures in virus-seeded lettuce and whipped cream ${ }^{a}$

\begin{tabular}{|c|c|c|c|c|c|c|c|}
\hline \multirow[b]{2}{*}{ Food } & \multirow[b]{2}{*}{ Method } & \multicolumn{3}{|c|}{ TRIzol } & \multicolumn{3}{|c|}{ RNeasy Mini Kit } \\
\hline & & $\begin{array}{l}\text { Viral } \\
\text { input }\end{array}$ & $\begin{array}{l}\text { Virus } \\
\text { recovery }\end{array}$ & $\begin{array}{l}\text { Loss of } \\
\text { input virus }\end{array}$ & $\begin{array}{l}\text { Viral } \\
\text { input }\end{array}$ & $\begin{array}{l}\text { Virus } \\
\text { recovery }\end{array}$ & $\begin{array}{l}\text { Loss of } \\
\text { input virus }\end{array}$ \\
\hline \multirow[t]{3}{*}{ Lettuce } & PEG-NaCl & $10^{5}$ & $10^{3}$ & 100 & $10^{6}$ & $10^{4}$ & 100 \\
\hline & Ultracentrifugation & $10^{5}$ & $10^{3}$ & 100 & $10^{5}$ & $10^{4}$ & 10 \\
\hline & Ultrafiltration & $10^{5}$ & $10^{2}$ & 1,000 & $10^{5}$ & $10^{3}$ & 100 \\
\hline \multirow[t]{2}{*}{ Cream } & PEG-NaCl & $10^{5}$ & $10^{4}$ & 10 & $10^{6}$ & $10^{4}$ & 100 \\
\hline & Ultrafiltration & $10^{5}$ & $10^{3}$ & 100 & $10^{6}$ & $10^{3}$ & 1,000 \\
\hline
\end{tabular}

${ }^{a}$ Duplicate 10 -fold dilutions were tested. 
TABLE 3. Seven norovirus-associated foodborne gastroenteritis outbreaks in 2002 and food items implicated in each outbreak

\begin{tabular}{cll}
\hline Outbreak no. & \multicolumn{1}{c}{ Outbreak date } & Implicated norovirus \\
\hline 1 & January 2002 & Not specified \\
2 & November 2002 & Birmingham \\
3 & September 2002 & Birmingham \\
4 & October 2002 & Grimsby \\
5 & November 2002 & Grimsby \\
6 & November 2002 & Not specified \\
7 & November 2002 & Not specified \\
\hline
\end{tabular}

PCR-positive product revealed no norovirus-specific sequence.

To control for possible inhibition in the samples, 40 of the 42 food items tested were seeded with $\mathrm{CaCV}$ at $2.5 \times$ $10^{4}$ TCID $_{50}$. The loss of virus input was determined by analysis of 10-fold serial dilutions of the RNA by RT-PCR followed by hybridization of the RT-PCR products. Virus loss ranged from 1 to $5 \mathrm{log}$ units; $38 \%$ of the food items had a $1-\log$ virus loss, $33 \%$ had a $2-\log \operatorname{loss}, 20 \%$ had a $3-$ $\log \operatorname{loss}, 5 \%$ had a $4-\log \operatorname{loss}$, and $5 \%$ had a $5-\log \operatorname{loss}$ (Table 4). Of all food items, the meat products produced the least inhibition with the $\mathrm{PEG}-\mathrm{NaCl}$ precipitation-TRIzol procedure; from $25 \%$ of the items with 1-log virus loss to $3 \%$ with a $5-\log$ loss. For grain products, more inhibition was obtained with the same procedure.

Food items with a more than 2-log virus loss (30\%) were tested with an alternative procedure. Eleven food items were retested, 10 complex food items with the ultracentrifugation-RNeasy Mini Kit procedure and one homogeneous food item with the ultrafiltration-RNeasy Mini Kit procedure. The virus loss in these retested food items ranged from 1 to $5 \mathrm{log}$ units. One product had a 4-log increase in virus recovery in the second procedure, three food items had a 3-log increase, two food items had a 2$\log$ increase, three food items had a 1-log increase, and only two food items showed no improvement. Spiced and nonspiced food items such as applesauce with cinnamon and pepper pâté had a 5-log virus loss with the PEG- $\mathrm{NaCl}$ precipitation-TRIzol procedure. Both food items were retested with the alternative procedure ultracentrifugation-RNeasy Mini Kit, which resulted in a significant improvement in recovery of seeded virus from pepper pâté but not from applesauce with cinnamon. Some food items had low $\mathrm{pH}$, e.g., pickled salad ( $\mathrm{pH}$ 4.9) and pickled ice ( $\mathrm{pH}$ 6.2). By adjusting the $\mathrm{pH}$ to 9.5 with $1 \mathrm{M} \mathrm{NaOH}$, a 1-log (ice) or $2-\log$ (salad) improvement in virus recovery was achieved. Although virus loss was highly reduced in some cases, no noroviruses were detected in the food items.

\section{DISCUSSION}

Several virus concentration and RNA extraction methods were applied to different food items suspected to be causes of various disease outbreaks. Seeding experiments revealed that for food groups, such as dairy and fruits or vegetables, virus concentration methods and RNA extraction methods differed in the efficiency of virus recovery. These differences may be explained either by the way the food item was prepared, e.g., cooking or mashing, the composition of the food item, e.g., the degree of fats, proteins, or polysaccharides, or the matrix of the food item, e.g., solid or liquid. The virus concentration methods compared in this study were precipitation, ultracentrifugation, and ultrafiltration. However, not all of these methods were appropriate for all kinds of food. For instance, a virus concentration procedure based on filtration can be more successfully used on food items with a solid matrix, which produce a clear eluate after the virus is washed from the food item. Products with high amounts of fat are not ultracentrifuged because excessive fat components will accumulate on top of the supernatant, making it more difficult to remove the supernatant and subsequently extract viral RNA. We found that the optimal method for concentration of whipped cream (a dairy product) was PEG precipitation, because filters get clogged and centrifugation yields a voluminous pellet. The ultracentrifugation concentration method was optimal for lettuce, a food item with a solid matrix that may be washed off and whose eluate can be concentrated with ultracentrifugation. RNA extraction from lettuce eluate was more efficient with the RNeasy Mini Kit than with TRIzol probably because inhibitors are less well-extracted with the silica beads. However, RNA extraction by use of TRIzol was preferred over the RNeasy Mini Kit to remove fat components and proteins, which are present in meat and dairy products. RNA extraction by use of the RNeasy Mini Kit is specialized for removal of polysaccharides, which are present in food items such as vegetables and shellfish.

In this study, food items were categorized into four groups: dairy (9 items), meat (20 items), fruit or vegetable ( 8 items), and grain (5 items). A fifth category not analyzed in this study is beverages. Seeding experiments were done to develop efficient procedures for virus detection in lettuce and whipped cream as representatives of the fruits and vegetables and the dairy products, respectively. In the viral disease outbreaks, however, many other food items were implicated, and the samples were often mixed during collection. The efficiency of the procedures for the other food groups (meat, grains, and beverages) was not tested in seeding experiments. However, meat processed by the PEG$\mathrm{NaCl}$ precipitation-TRIzol procedure had the least inhibition compared with the other food items, such as grains. A rapid standardized procedure was developed previously for shellfish (31). In the present study, inhibition of virus detection in foods was determined by adding external virus to the food item. A better way to control for inhibition would be the addition of an internal RNA control (38). Such an approach was applied for the development of internal controls for norovirus and rotavirus in water samples by amplifying a $\beta$-globine fragment with $\beta$-globine primers coupled with norovirus or rotavirus primers (30). The primer- $\beta$-globine DNA products were cloned, and RNA was synthesized with T7 RNA polymerase. These internal controls could be very useful for future optimization of virus concentration and RNA extraction procedures and for investigating gastroenteritis outbreaks.

Because food items are not expected to be contaminated with high concentrations of pathogenic viruses, in- 
TABLE 4. Food items implicated in norovirus-associated gastroenteritis outbreaks

\begin{tabular}{|c|c|c|c|c|c|c|}
\hline Procedure 1 & $\begin{array}{l}\text { Food } \\
\text { group }^{a}\end{array}$ & Food item & $\begin{array}{c}\text { Outbreak } \\
\text { no. }{ }^{b}\end{array}$ & Virus loss & Procedure $2^{c}$ & Virus loss \\
\hline \multirow[t]{39}{*}{ PEG-TRIzol } & \multirow[t]{9}{*}{$\mathrm{D}$} & Cheese & 3 & 10 & NT & NT \\
\hline & & Whipped cream & 1 & 10 & NT & NT \\
\hline & & Chocolate mousse & 4 & 10 & NT & NT \\
\hline & & Cream cheese & 5 & 100 & NT & NT \\
\hline & & Vanilla ice & 3 & 1,000 & UC/RNeasy & 10 \\
\hline & & Yogurt + applesauce & 4 & 1,000 & UC/RNeasy & 100 \\
\hline & & Strawberry ice & 3 & 1,000 & UC/RNeasy & 1,000 \\
\hline & & Whipped cream & 2 & $\mathrm{NS}^{d}$ & NS & NS \\
\hline & & Strawberry + whipped cream & 2 & NS & NS & NS \\
\hline & \multirow[t]{5}{*}{ G } & Macaroni & 4 & 100 & NT & NT \\
\hline & & Pancake & 5 & 100 & NT & NT \\
\hline & & Rye bread & 5 & 100 & NT & NT \\
\hline & & White bread & 3 & 100 & NT & NT \\
\hline & & Potatoes & 3 & 1,000 & UC/RNeasy & 10 \\
\hline & \multirow[t]{20}{*}{ M } & Meat with gravy & 4 & 10 & NT & NT \\
\hline & & Codfish & 6 & 10 & NT & NT \\
\hline & & Salmon salad & 7 & 10 & NT & NT \\
\hline & & Meat + breadcrumbs & 4 & 10 & NT & NT \\
\hline & & Meat slices & 3 & 10 & NT & NT \\
\hline & & Meat slices & 5 & 10 & NT & NT \\
\hline & & Chicken stew & 6 & 10 & NT & NT \\
\hline & & Duck mousse & 7 & 10 & NT & NT \\
\hline & & Eel & 1 & 10 & NT & NT \\
\hline & & Salad (Russian) & 3 & 10 & NT & NT \\
\hline & & Boiled egg & 3 & 100 & NT & NT \\
\hline & & Boiled egg & 5 & 100 & NT & NT \\
\hline & & Meatball + sauce & 5 & 100 & NT & NT \\
\hline & & Smoked salmon & 7 & 100 & NT & NT \\
\hline & & Salmon + cheese & 5 & 100 & NT & NT \\
\hline & & Salmon & 3 & 1,000 & UC/RNeasy & 0 \\
\hline & & Sausage & 3 & 1,000 & UC/RNeasy & 0 \\
\hline & & Crab salad & 7 & 1,000 & UC/RNeasy & 100 \\
\hline & & Pork & 3 & 1,000 & UC/RNeasy & 100 \\
\hline & & Pepper paté & 3 & 100,000 & UC/RNeasy & 10 \\
\hline & \multirow[t]{5}{*}{$\mathrm{V}$} & Tomato & 3 & 10 & NT & NT \\
\hline & & Ginger & 3 & 10 & NT & NT \\
\hline & & Pickled ice, pH 6.2 & 3 & 100 & NT & NT \\
\hline & & Pickled salad, pH 4.9 & 3 & 10,000 & NT & NT \\
\hline & & Applesauce + cinnamon & 3 & 100,000 & UC/RNeasy & 100,000 \\
\hline \multirow[t]{3}{*}{ Ultracentrifugation-RNeasy } & \multirow[t]{3}{*}{$\mathrm{V}$} & Vegetable soup & 4 & 100 & NT & NT \\
\hline & & Cauliflower & 4 & 100 & NT & NT \\
\hline & & Leek & 4 & 10,000 & UF/RNeasy & 10 \\
\hline
\end{tabular}

${ }^{a} \mathrm{D}$, dairy; M, meat; $\mathrm{V}$, vegetables; $\mathrm{G}$, grains.

${ }^{b}$ For outbreak number, see Table 3 .

${ }^{c} \mathrm{NT}$, not tested with the alternative procedure; UC, ultracentrifugation; UF, ultrafiltration.

${ }^{d} \mathrm{NS}$, not tested in the seeding experiment.

hibition or viral RNA loss of 1 to $5 \log$ units indicates insufficient sensitivity. Additional steps are needed for the removal of inhibitors from food extracts to allow detection of these low virus concentrations. Recent advances in method development should be incorporated in the proposed procedure to further improve virus detection in food items. For instance, the recent availability of magnetic silica beads resulted in a significant improvement in removal of inhibitors during extraction of RNA from concentrated water samples (41). Such methods also may lead to improvements in procedures for detection of viruses in foods.

The food items analyzed for the presence of pathogenic viruses were collected from norovirus-associated gastroenteritis outbreaks and therefore had a reasonable chance of containing norovirus. However, all food items tested were negative for the virus. This negative result could be due to coprecipitation of inhibitors during virus concentration and RNA extraction, or the wrong portion of the food item may 
TABLE 5. Adjustments to washing steps 1 and 2 for the three virus concentration methods

\begin{tabular}{|c|c|c|c|}
\hline Method & Wash step 1 & Wash step 2 & Concentration step \\
\hline PEG-NaCl precipitation & $\begin{array}{l}4 \mathrm{ml} \text { of } \mathrm{PBS} \text {, vortex, incubate } 10 \mathrm{~min} \\
\text { at room temp, centrifuge } 10 \mathrm{~min} \text { at } \\
4,000 \times g \text { (twice) }\end{array}$ & $\begin{array}{l}5 \mathrm{ml} \text { of Vertrel, vortex, incubate } 10 \\
\text { min at room temp, centrifuge } 10 \\
\text { min at } 4,300 \times g\end{array}$ & \\
\hline Ultracentrifugation & $\begin{array}{l}4 \mathrm{ml} \text { of } \mathrm{PBS} \text {, vortex, incubate } 10 \mathrm{~min} \\
\text { at room temp, centrifuge } 10 \mathrm{~min} \text { at } \\
4,000 \times g \text { (twice) }\end{array}$ & $\begin{array}{l}5 \mathrm{ml} \text { of Vertrel, vortex, incubate } 10 \\
\mathrm{~min} \text { at room temp, centrifuge } 10 \\
\text { min at } 4,300 \times g\end{array}$ & $\begin{array}{l}\text { Ultracentrifugation } 3 \mathrm{~h} \\
\quad \text { at } 120,000 \times g\end{array}$ \\
\hline Ultrafiltration & $\begin{array}{l}\text { Glycine buffer, adjust } \mathrm{pH} \text { to } \geq 9.5 \text {, in- } \\
\text { cubate } 10 \mathrm{~min} \text { at room temp, centri- } \\
\text { fuge } 10 \mathrm{~min} \text { at } 4,000 \times g \text { (twice) }\end{array}$ & Centrifuge $10 \mathrm{~min}$ at $4,300 \times g$ & \\
\hline
\end{tabular}

have been tested because of heterogeneous contamination from food handling. Because the infectious dose of norovirus can be as low as a few particles (16), these few particles could easily be lost during the multiple virus concentration and extraction steps. Another possible problem is that the true contaminated food item might not have been available for testing. Food items were implicated as causes of outbreaks mainly based on descriptive information and not on analytical case-control or cohort studies. In our study, other generic primer sets were applied if lower sensitivity of detection was expected based on information on norovirus variants detected in fecal samples of affected individuals. However, specific primer sets could be selected and tested, though this requires more time in large outbreaks. Such an approach was successfully employed in an outbreak related to contaminated water (19) and raspberries (28).

Quantitative detection of viruses has been achieved by various assays such as nucleic acid sequence-based amplification, Lightcycler, and Taqman $(15,22,26,41)$. Quantitative virus detection in foods is important for estimation of the risk of infection from food consumption. Dutch legislation concerning pathogens in drinking water requires producers to limit the yearly infection risk to less than 1 in 10,000 exposed consumers. Policy makers should decide on an acceptable risk of infection from consumption of virus-contaminated foods. Because PCR-detectable units do not necessarily represent infectious particles, additional information on the infectivity of the detected virus is needed to prevent overestimation of the infection risk associated with consumption of a specific food item. However, natural hepatitis A virus isolates are not easy to culture in vitro, and noroviruses currently cannot be cultured at all (13).

This study was conducted to address the detection of one of the most important foodborne viruses, norovirus. However, other important food- and waterborne viruses causing either serious illness or large disease outbreaks should be considered. For instance, hepatitis A and hepatitis E viruses have been associated previously with serious foodborne diseases $(4,45)$. Recently, enteroviruses caused meningitis in hundreds of bathers in Germany (17). In The Netherlands, enteroviruses have been found in surface waters (41) and oysters (31).

\section{ACKNOWLEDGMENTS}

This investigation was performed for the Dutch Food Safety Authority within the framework of project V/330020, "Foodborne virus infections."

\section{REFERENCES}

1. Ando, T., J. S. Noel, and R. L. Fankhauser. 2000. Genetic classification of "Norwalk-like viruses." J. Infect. Dis. 181:S336-S348.

2. Boom, R., C. J. Sol, M. M. Salimans, C. L. Jansen, P. M. Wertheim van Dillen, and J. S. O. van der Noordaa. 1990. Rapid and simple method for purification of nucleic acids. J. Clin. Microbiol. 28:495503.

3. Bosch, A., G. Sanchez, F. Le Guyader, H. Vanaclocha, L. Haugarreau, and R. M. Pinto. 2001. Human enteric viruses in Coquina clams associated with a large hepatitis A outbreak. Water Sci. Technol. 43:61-65.

4. Calder, L., G. Simmons, C. Thornley, P. Taylor, K. Pritchard, G. Greening, and J. Bishop. 2003. An outbreak of hepatitis A associated with consumption of raw blueberries. Epidemiol. Infect. 131:745751.

5. Calderon-Margalit, R. S. R., T. Halperin, N. Orr, D. Cohen, and T. Shohat. 2005. A large-scale gastroenteritis outbreak associated with Norovirus in nursing homes. Epidemiol. Infect. 133:35-40.

6. Chadwick, P. R., and R. Mc Cann. 1994. Transmission of a small round structured virus by vomiting during a hospital outbreak of gastroenteritis. J. Hosp. Infect. 26:251-259.

7. Ciocca, M. 2000. Clinical course and consequences of hepatitis A infection. Vaccine 18(Suppl. 1):71-74.

8. Croci, L., D. De Medici, C. Scalfaro, A. Fiore, and L. Toti. 2002. The survival of hepatitis A virus in fresh produce. Int. J. Food Microbiol. 73:29-34.

9. Daniels, N. A., D. A. Bergmire-Sweat, K. J. Schwab, K. A. Hendricks, S. Reddy, S. M. Rowe, R. L. Fankhauser, S. S. Monroe, R. L. Atmar, R. I. Glass, and P. S. Mead. 2000. A foodborne outbreak of gastroenteritis associated with Norwalk-like viruses: first molecular traceback to sandwiches contaminated during preparation. $\underline{J \text {. In- }}$ fect. Dis. 181:1467-1470.

10. De Serres, G., T. L. Cromeans, B. Levesque, N. Brassard, C. Barthe, M. Dionne, H. Prud'homme, D. Paradis, G. N. Shapiro, O. V. Nainan, and H. S. Margolis. 1999. Molecular confirmation of hepatitis A virus from well water: epidemiology and public health implications. J. Infect. Dis. 179:37-43.

11. Dubois, E., C. Agier, O. Traore, C. Hennechart, G. Merle, C. Cruciere, and H. Laveran. 2002. Modified concentration method for the detection of enteric viruses on fruits and vegetables by reverse transcriptase-polymerase chain reaction or cell culture. J. Food Prot. 65:1962-1969.

12. Duizer, E., P. Bijkerk, B. Rockx, A. De Groot, F. Twisk, and M. Koopmans. 2004. Inactivation of caliciviruses. Appl. Environ. Microbiol. 70:4538-4543.

13. Duizer, E., K. J. Schwab, F. H. Neill, R. L. Atmar, M. P. G. Koop- 
mans, and M. K. Estes. 2004. Laboratory efforts to cultivate noroviruses. J. Gen. Virol. 85:79-87.

14. Fankhauser, R. L., S. S. Monroe, J. S. Noel, C. D. Humphrey, J. S. Bresee, U. D. Parashar, T. Ando, and R. I. Glass. 2002. Epidemiologic and molecular trends of "Norwalk-like viruses" associated with outbreaks of gastroenteritis in the United States. J. Infect. Dis. 186:1-7.

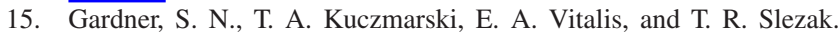
2003. Limitations of Taqman PCR for detecting divergent viral pathogens illustrated by hepatitis A, B, C, and E viruses and human immunodeficiency virus. J. Clin. Microbiol. 41:2417-2427.

16. Green, K. Y., R. M. Chanok, and A. Z. Kapikian. 2002. Human caliciviruses, p. 841-874. In D. M. Knipe and P. M. Howley (ed.), Fields virology, 4th ed. Lippincott, Williams and Wilkins, Philadelphia.

17. Hauri, A. M., M. Schimmelpfennig, M. Walter-Domes, A. Letz, S. Diedrich, J. Lopez-Pila, and E. Schreier. 2005. An outbreak of viral meningitis associated with a public swimming pond. Epidemiol. Infect. 133:291-298.

18. Heller, D., O. N. Gill, E. Raynham, T. Kirkland, P. M. Zadick, and R. Stanwell-Smith. 1986. An outbreak of gastrointestinal illness associated with consumption of raw depurated oysters. Br. Med. J. 292:1726-1727.

19. Hoebe, C. J. P. A., H. Vennema, A. M. de Roda Husman, and Y. T. H. P. van Duynhoven. 2004. Norovirus outbreak among primary school children who had played in a recreational water fountain. $J$. Infect. Dis. 189:699-705.

20. Hutin, Y. J. F., V. Pool, E. H. Cramer, O. V. Nainan, J. Weth, I. T. Williams, S. T. Goldstein, K. F. Gensheimer, B. P. Bell, C. N. Shapiro, M. J. Alter, H. S. Margolis, and the National Hepatitis A Investigation Team. 1999. A multistate, foodborne outbreak of hepatitis A. N. Engl. J. Med. 340:595-602.

21. Isakbaeva, E. T., M. Widdowson, R. S. Beard, S. N. Bulens, J. Mullins, S. S. Monroe, J. Bresee, P. Sassano, E. H. Cramer, and R. I. Glass. 2005. Norovirus transmission on cruise ships. Emerg. Infect. Dis. 11:154-157.

22. Kageyama, T., S. Kojima, M. Shinohara, K. Uchida, S. Fukushi, F B. Hoshino, N. Takeda, and K. Katayama. 2003. Broadly reactive and highly sensitive assay for Norwalk viruses based on real-time quantitative reverse transcription-PCR. J. Clin. Microbiol. 41:15481557.

23. Kilgore, P. E., E. D. Belay, and D. M. Hamlin. 1996. A university outbreak of gastroenteritis due to a small-round-structured virus: application of molecular diagnostics to identify the etiologic agent and patterns of transmission. J. Infect. Dis. 173:787-793.

24. Koff, R. S. 1998. Hepatitis A. Lancet 351:1643-1649.

25. Koopmans, M., and E. Duizer. 2004 . Foodborne viruses: an emerging problem. Int. J. Food Microbiol. 90:23-41.

26. Laverick, M. A., A. P. Wyn-Jones, and M. J. Carter. 2004. Quantitative RT-PCR for the enumeration of noroviruses (Norwalk-like viruses) in water and sewage. Lett. Appl. Microbiol. 39:127-136.

27. Le Guyader, F., E. Dubois, D. Menard, and M. Pommepuy. 1994. Detection of hepatitis A virus, rotavirus, and enterovirus in naturally contaminated shellfish and sediment by reverse transcription-seminested PCR. Appl. Environ. Microbiol. 60:3665-3671.

28. Le Guyader, F. S., C. Mittelholzer, L. Haugarreau, K. Hedlund, R. Alsterlund, M. Pommepuy, and L. Svensson. 2004. Detection of noroviruses in raspberries associated with a gastroenteritis outbreak. Int. J. Food Microbiol. 97:179-186.

29. Le Guyader, F. S., A.-C. Schultz, L. Haugarreau, L. Croci, L. Maunula, E. Duizer, F. Lodder-Verschoor, C.-H. von Bonsdorff, E. Suffredini, W. H. M. van der Poel, R. Reymundo, and M. Koopmans. 2004. Round-robin comparison of methods for the detection of human enteric viruses in lettuce. J. Food Prot. 67:2315-2319.

30. Lodder, W. J., H. H. J. L. van den Berg, S. A. Rutjes, and A. M. de Roda Husman. Unpublished data.

31. Lodder-Verschoor, F., A. M. de Roda Husman, H. H. J. L. van den Berg, A. Stein, H. M. L. van Pelt-Heerschap, and W. H. M. van der Poel. 2005. Year-round screening of noncommercial and commercial oysters for the presence of human pathogenic viruses. J. Food Prot. 68:1853-1859.

32. Lopman, B., H. Vennema, E. Kohli, P. Pothier, A. Sanchez, A. Negredo, J. Buesa, E. Schreier, M. Reacher, D. Brown, J. Gray, M. Iturriza, C. Gallimore, B. Bottiger, K. O. Hedlund, M. Torven, C.-H. von Bonsdorff, L. Maunula, M. Poljsak-Prijatelj, J. Zimsek, G. Reuter, G. Szucs, B. Melegh, L. Svennson, Y. van Duijnhoven, and M. Koopmans. 2004. Increase in viral gastroenteritis outbreaks in Europe and epidemic spread of new norovirus variant. Lancet 363: 682-688.

33. Matsumoto, K., M. Hatano, K. Kobayashi, A. Hasegawa, S. Yamazaki, S. Nakata, S. Chiba, and Y. Kimura. 1989. An outbreak of gastroenteritis associated with acute rotaviral infection in school children. J. Infect. Dis. 160:611-615.

34. McCarthy, M., M. K. Estes, and K. C. Hyams. 2000. Norwalk-like virus infection in military forces: epidemic potential, sporadic disease and the future direction of prevention and control efforts. $J$. Infect. Dis. 181:387-391.

35. Mendez, I. I., L. L. Hermann, P. R. Hazelton, and K. M. Coombs 2000. A comparative analysis of freon substitutes in the purification of reovirus and calicivirus. J. Virol. Methods 90:59-67.

36. Parashar, U. D., L. Dow, and R. Fankhauser. 1998. An outbreak of viral gastroenteritis associated with consumption of sandwiches: implications for the control of transmission by food handlers. Epidemiol. Infect. 121:615-621.

37. Pebody, R. G., T. Leina, P. Ruutu, L. Kinnunen, I. Davidkin, H. Nohynek, and P. Leinikki. 1998. Foodborne outbreaks of hepatitis A in a low endemic country: an emerging problem? Epidemiol. Infect. 120:55-59.

38. Pinelli, E., S. Y. van der Kaaij, C. P. M. Broeren, E. J. Ruitenberg, and V. P. M. G. Rutten. 1999. Measurement of dog cytokines by reverse transcription-quantitative competitive polymerase chain reaction. Immunogenetics 49:696-699.

39. Potasman, I., A. Paz, and M. Odeh. 2002. Infectious outbreaks associated with bivalve shellfish consumption: a worldwide perspective. Clin. Infect. Dis. 35:921-928.

40. Rosenblum, L. S., I. R. Mirkin, D. T. Allen, D. Safford, and S. C. Hadler. 1990. A multifocal outbreak of hepatitis A traced to commercially distributed lettuce. Am. J. Public Health 80:1075-1080.

41. Rutjes, S. A., R. Italiaander, H. H. J. L. van den Berg, W. J. Lodder, and A. M. de Roda Husman. 2005. Isolation and detection of enterovirus RNA from large-volume water samples by using the NucliSens miniMAG system and real-time nucleic acid sequencebased amplification. Appl. Environ. Microbiol. 71:3734-3740.

42. Sair, A. I., D. H. D’Souza, C. L. Moe, and L. A. Jaykus. 2002. Improved detection of human enteric viruses in foods by RT-PCR. J. Virol. Methods 100:57-69.

43. Schwab, K. J., F. H. Neill, R. L. Fankhauser, N. A. Daniels, S. S. Monroe, D. A. Bergmire-Sweat, M. K. Estes, and R. L. Atmar. 2000. Development of methods to detect Norwalk-like viruses (NLVs) and hepatitis A virus in delicatessen foods: application to a food-borne NLV outbreak. Appl. Environ. Microbiol. 66:213-218.

44. Svensson, L. 2000. Diagnosis of foodborne viral infections in patients. Int. J. Food Microbiol. 59:117-126.

45. Tei, S., N. Kitajima, S. Ohara, Y. Inoue, M. Miki, T. Yamatani, H. Yamabe, S. Mishiro, and Y. Kinoshita. 2004. Consumption of uncooked deer meat as a risk factor for hepatitis E virus infection: an age- and sex-matched case-control study. J. Med. Virol. 74:67-70.

46. Tei, S., N. Kitajima, K. Takakashi, and S. Mishiro. 2003. Zoonotic transmission of hepatitis $\mathrm{E}$ virus from deer to human beings. Lancet 362:371-373.

47. van den Berg, H. H. J. L., W. J. Lodder, W. van der Poel, H. Vennema, and A. M. de Roda Husman. 2005. Genetic diversity of noroviruses in raw and treated sewage water. Res. Microbiol. 156:532540.

48. van Duynhoven, Y. T. H. P., C. M. de Jager, L. M. Kortbeek, H. Vennema, M. P. G. Koopmans, F. van Leusden, W. H. M. van der Poel, and M. J. M. van den Broek. 2005. A one-year intensified study of outbreaks of gastroenteritis in The Netherlands. Epidemiol. Infect. 133:9-21.

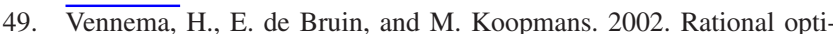


mization of generic primers used for Norwalk-like virus detection by reverse transcriptase polymerase chain reaction. J. Clin. Virol. 25:233-235.

50. Vinjé, J., S. A. Altena, and M. P. G. Koopmans. 1997. The incidence and genetic variability of small round-structured viruses in outbreaks of gastroenteritis in The Netherlands. J. Infect. Dis. 176:1374-1378.

51. Vinjé, J., R. A. Hamidjaja, and M. D. Sobsey. 2004. Development and application of a capsid VP1 (region D) based reverse transcription PCR assay for genotyping of genogroup I and II noroviruses. J. Virol. Methods 116:109-117.

52. Yeats, J., H. Smuts, C. J. Serfontein, and J. Kannemeyer. 2005. Investigation into a school enterovirus outbreak using PCR detection and serotype identification based on the $5^{\prime}$ non-coding region. Epidemiol. Infect. 133:1123-1130. 